\title{
The Influence of the Polish-Russian Border on the Development Opportunities of the Polish Border Region
}

\author{
Tomasz MICHALSKI ${ }^{*}$ \\ ${ }^{*}$ Corresponding author \\ ${ }^{1}$ University of Gdańsk, Faculty of Oceanography and Geography, Department of Regional Development, Gdańsk, POLAND \\ E-mail: tomasz.michalski@ug.edu.pl \\ DOI: 10.24193/JSSP.2019.2.02 \\ https://doi.org/10.24193/JSSP.2019.2.02
}

K e y w o r d s: Polish-Russian border, Poland, Kaliningrad Oblast, local development, border region

\begin{abstract}
A B S T R A C T
The aim of the study is to analyse the conditions for the development of Polish poviats (equivalent to level 1 local administrative units) located on the Polish-Russian border. The introduction to the article presents general determinants of the development of border areas in post-communist countries. The next section provides the main analysis. SWOT analysis was used because it enabled holistic analysis of all potential factors of development of the region. It was found that the internal factors of the development of the region (e.g. financial resources, level of development of transport infrastructure, human resources) are weak, except for ecological factors related to the beauty of a post-glacial landscape. Exogenous factors of development are mainly associated with receiving EU funds (a positive factor), the peripheral location in the European Union and high instability of the functioning of the Polish-Russian border (negative factors). The high instability of the Polish-Russian border's functioning related to the huge influence of political relations between NATO and the EU on the one hand and Russia on the other hand prevents local governments from drawing up long-term development strategies based on the functioning of this border.
\end{abstract}

\section{INTRODUCTION}

In the European countries, now called postcommunist, a whole series of processes of political transformation took place after 1989, which changed the conditions and the quality of life of their citizens, for example, the promotion of democracy (Freyburg et al., 2009), liberalization of the economy (Roaf et al., 2014), state institutional reforms (Fritz, 2007), public administration reform (Nemec, 2014). These processes also translate into the regional and local level (Chapman and Meliciani, 2018; Ezcurra et al., 2007). It is most clearly visible in the case of changes in the significance of particular regions and the functions performed by the national borders.

Looking at the substantial changes in the importance of regions in the analysed part of Europe, two processes become apparent. The first one is an increase in the importance of metropolitan areas, especially those comprising the national capitals (Egidy, 2017; Salukvadze and Golubchikov, 2016). The second one is the decline and depopulation of various regions, including the rural ones situated peripherally (Kriaučiūnas et al., 2014; Mladenov and Ilieva 2012).

In the latter case, we are dealing with changes in the significance of national borders. The most important change is to enable the citizens of these countries to move outside their own countries. After some post-communist countries had integrated into the European Union, far-reaching changes in the functions of borders in this area took place. The external borders of the enlarged European Union still remained hardly permeable to a greater (e.g. the Polish-Russian, Lithuanian-Russian, Romanian-Ukrainian borders) or 
to a slightly smaller extent (e.g. the Hungarian-Serbian or Croatian-Bosnian borders). However, borders within the enlarged European Union have become very permeable, more where the countries were simultaneously members of the Schengen Area (e.g. the Polish-Lithuanian borders, the Hungarian-Slovak borders), slightly less where the countries being in the EU were not members of the Schengen Area (e.g. the Romanian-Bulgarian border, the Croatian-Slovenian border) (Golunov, 2016; Ilieş and Grama, 2010; Zupančič et al., 2018; Ilieş et al., 2011). This, of course, has also translated into the functioning of border regions. The regions located near the intra-EU borders gained the most, as these borders ceased to act as barriers. On the opposite pole, there are regions that suddenly became cross-border ones due to the emergence of new borders (e.g. the border between South Ossetia and Georgia, the border between Crimea and the rest of Ukraine). In between there are border regions along the thus far existing borders that have not become intra-EU ones (Hergezelová, 2017; Ilieş et al., 2010; Xheneti et al., 2013; Vodichev et al., 2016; Szymańska, 2016; German, 2016).

The common point of the two spatial dimensions of transformation processes discussed above is the changes taking place in the border areas. While in the case of borders between the European Union member states, the impact of these borders is currently low (because they do not constitute a spatial or institutional barrier), in the case of borders between countries that are not members of the EU/EFTA or the Union State of Russia and Belarus and in the case of external borders of the EU - the existence of these borders still has an overwhelming impact on border areas (because these borders still function as a more or less strong spatial and institutional barrier). This is particularly pronounced with people or goods trying to cross borders, which is time consuming and burdensome. It also impedes cooperation between regions located on both sides of the border. In such a situation, the border, acting as a barrier, enhances e.g. the peripheralisation of the border region, making it less attractive for investment, but also for inhabitants. This is clearly evident in the case of Euroregions, which cover three or more countries both belonging and not belonging to EU/EFTA (Grigorescu et al., 2016; Stokłosa, 2012).

Hence, the main objective of the study is to analyse the impact of the Polish-Russian border on the development opportunities of the area directly adjacent to the Polish side of the border. Multiple depictions of the border are possible, e.g. as a barrier (Więckowski, 2001), a metaphor (Nikiforova, 2010), an institution (Mielnik, 2006), etc. This study treated the border as a barrier whose permeability to goods and services is conditioned by its political character (i.e. decisions taken by the authorities of the two countries divided by this border). The timeframe of the study covers the period after Poland's accession to the European Union, which greatly determined the significance of the mentioned border, as it has become an external border of the EU. The suggested thesis is that overdependence of the function of this border on political decisions taken in Brussels, Warsaw and Moscow makes it difficult to treat it as a stable pro-development factor.

\section{METHODS AND DATA SOURCES}

The research area was defined as a border area, since the state border between Poland with Russia, which is also the external border of the European Union, constitutes its northern boundary. Thus, this area meets the basic condition for being a border area. It is also a peripheral area in spatial and not functional terms. This means that in the scale of both Poland and the European Union it is located far from the centres of political and economic life and is hardly accessible in terms of transportation (Miszczuk, 2013). The analysed area covers poviats (counties LAU-1) located on the Polish side of the border with Russia, and more precisely with its exclave - the Kaliningrad Oblast; precisely there are 5 poviats (bartoszycki, braniewski, kętrzyński, gołdapski and węgorzewski) located in the Warmian-Masurian Voivodeship and the nowodworski poviat in the Pomeranian Voivodeship. The latter was excluded from analysis because its border with the Kaliningrad Oblast is located on the Vistula Spit and is very short therefore, the bordering with this district has practically no significance for this poviat (Fig. 1).

The peripheral location, both in Poland and in the European Union - which obviously negatively affects its development prospects - is an important feature of this area.

Local development is also used in the paper. There are two basic criteria distinguishing the definitions of local development (Sekuła, 2012): [1] from the viewpoint of the local community and its needs and [2] from the viewpoint of the changes taking place within the local arrangement. The second approach has been adopted in the paper, because it facilitates the analysis of the impact of the PolishRussian border on the development of the studied area.

It is thought that the SWOT analysis (Pahl and Richter, 2007) is the basic tool used to analyse the development opportunities of border regions. It has been considered as the basic method of analysis because it guarantees a holistic analysis of factors affecting the development of regions with a breakdown into: strengths, weaknesses, opportunities and threats. In addition, the analysis of development factors was used, broken down by: exogenous factors, endogenous factors, structural factors, and traditional factors (see: Ezcurra et al., 2007). The complementary role of this 
analysis in relation to the SWOT analysis was to focus on which development factors occurring in the analysed area could be classified as structural and which as traditional ones, and what the place of the state border among them is.

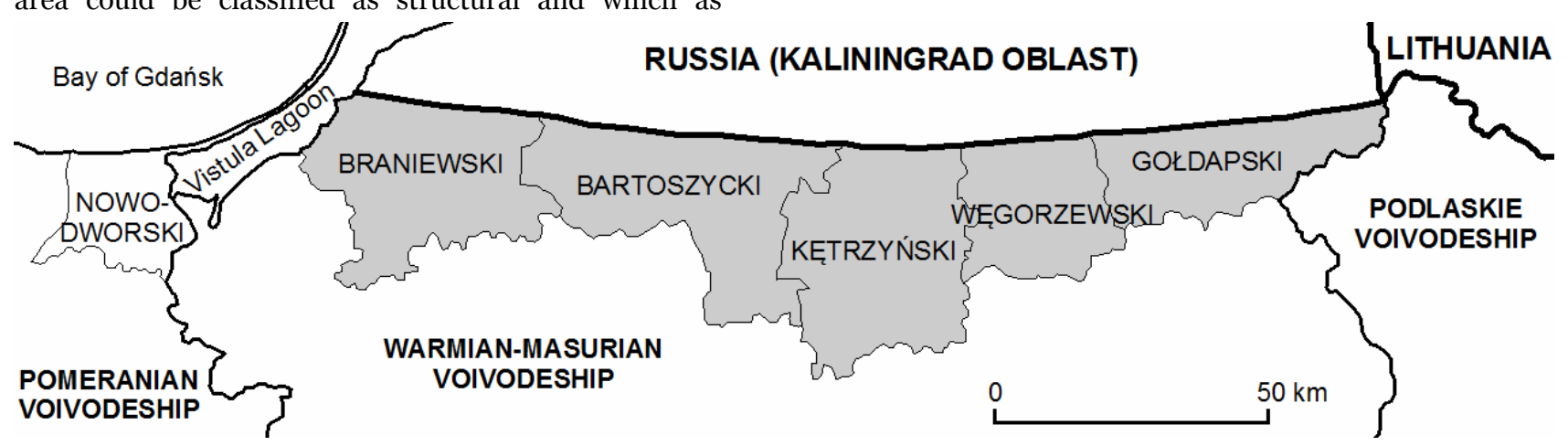

Fig. 1. Area of analysis (own elaboration).

Data collection was based on desk research (Czarniawska, 2014). According to the principles of triangulation - the data collected came from three main sources: (1) statistical data (regarding the population and border traffic) from government institutions: Local Data Bank and Border Guard; (2) selected studies (these were mainly documents containing development strategies) prepared for the needs of the selfgovernment of the Warmian-Masurian Voivodeship and individual poviat self-governments; (3) scientific publications.

\section{RESULTS AND DISCUSSION}

In accordance with the SWOT principles, the analysis was divided into four categories of strategic factors, of which the first two are internal factors and the next two are external ones.

In the case of the analysed poviats, among internal factors weaknesses predominate over strengths. This is confirmed by Godlewska-Majkowska's analysis (n.d.), because in its classification it included only pro-ecological activities, the strong development potentials of the Warmian-Masurian Voivodeship, the average human capital, living conditions of the population, accessibility, and the weak economy and innovativeness.

The relatively good condition of the natural environment is one of the clearly strong points of the area covered by the analysis (Kistowski, 2013). The analysed poviats belong entirely to the so-called "Green Lungs of Poland” (Polish: Zielone Płuca Polski w 2015 r., 2017). Therefore, rural tourism, which has been developing dynamically in Poland in recent years, is a great opportunity for the region. However, the discussed area is less developed in this respect than the neighbouring very attractive tourist regions (BednarekSzczepańska, 2017). Perhaps the reason for this is low transport accessibility. The second factor may be greater attractiveness of the so-called Great Masurian Lakes Region located more to the south for tourism and recreation. In the economic sphere, the analysed area, similarly to the whole Warmian-Masurian Voivodeship, for years has been one of the least developed in the country, with relatively low investment attractiveness and low innovativeness of economy (Borowicz et al., 2016; Godlewska-Majkowska, n.d.; Dziemianowicz and Szlachta, 2005). For example, in 2017 investment outlays in the Warmian-Masurian Voivodeship amounted to 5,075 PLN per capita, with an average for Poland of 6,712 PLN. Intramural expenditures on R\&D activity per capita in the Warmian-Masurian Voivodeship amounted to 184.5 PLN, with the average for Poland of 535.6 PLN (Local Data Bank). This results in a relatively bad situation on the labour market. If the registered unemployment rate in Poland in 2017 is assumed to be 100, its value in the five analysed districts ranged from 181.8 to 336.4 (Local Data Bank, 2019). Although regional authorities' planning documents assume economic growth, including an increase in the attractiveness of the Warmian-Masurian Voivodeship (Polish: Strategia Rozwoju społecznogospodarczego województwa warmińsko-mazurskiego do roku 2025, 2013; Polish: RSI - Regionalna Strategia Innowacyjności Województwa Warmińsko-Mazurskiego do roku 2020, 2010). However, it should be kept in mind that these are only intentions whose practical implementation depends on many factors. The province's specialisations include: water economics, high-quality food, and wood and furniture manufacturing. Of course, they may improve the inhabitants' living conditions, but they will not necessarily improve the position of the voivodeship in relation to other Polish regions (Dziemianowicz, 2017). Looking at the analysed area against the background of the voivodeship, it is predestined to develop the agricultural function (Gwiazdzinska-Goraj and Jezierska-Tholle, 2013), with the development of industry and services in cities (Godlewska-Majkowska, n.d.).

The border with Russia, which is the northern border of the studied area, is difficult to cross and there 
are relatively few border crossings. Looking at Poland's transport system, we can see that the system of main roads and railway lines bypasses this area (Komornicki et al., 2015). Only the main international expressway leading from Kaliningrad to the west (S22) passes through the braniewski poviat. None of the railway lines passing through the region is more important (even those linking Braniewo and Kaliningrad, which for several years have been used exclusively for freight traffic). The accessibility of public transport to the population is also very poor (Rosik et al., 2017). The recently opened Olsztyn-Mazury Airport is located within a short distance from this area. According to the plans, it should become an important development factor (Bogdański, 2014), but, for the time being, its pro-development impact on the region is small (in 2017 it served only 101,000 passengers (Polish: Size of Polish airports - passenger traffic and aircraft movements in domestic and international market in scheduled and charter services in 2015 - 2017, 2018). By contrast, in international terms, the Pan-European transport corridor No. I Branch A (Helsinki - Tallinn - Riga Kaunas - Kaliningrad - Gdańsk) passes through the western edge of the analysed area. Its infrastructure in the Gdańsk-Kaliningrad section is in a relatively average state (normal-gauge railway line: No. 9 and No. 204 and expressway: S7 and S22 on the Polish side). But for political-economic reasons (in particular, due to a lack of border control), the corridor No I. Branch B (Helsinki - Riga - Vilnius - Warsaw), bypassing the area in question from the east is much more often used for longitudinal transport. On the other hand, the transport corridor No. IX. Branch B (Kaliningrad Vilnius - Minsk - Gomel), which runs parallel from Kaliningrad to the border with Lithuania is of fundamental importance to the Kaliningrad region.

Ageing of the population is a serious factor negatively influencing the size of human resources in the analysed area. In 2017, people aged 70 and over constituted $8.9-10.9 \%$ of the population of the discussed districts. The rate of natural increase (except for the Gołdap poviat) was negative. Moreover, the net migration rate was also negative (Local Data Bank).

Looking at opportunities and concerns, we can clearly see the impact of two factors. The first one is the national policy. In addition to the support from standard EU and national funds, the analysed area also receives support from the additional national level assistance programme. It is the "Operational Programme Eastern Poland 2014-2020" (Polish: Program Operacyjny Polska Wschodnia 2014-2020), which covers five voivodeships located in the east of Poland and is focused on stimulating entrepreneurship and improving transport accessibility (especially railways). In addition, there is also an indirect impact of the presence of the European Union's external border in the east of Poland - this translates into different objectives and tasks of the Opole development strategy for the areas located at the eastern and western borders of the country (Smutek and Łonyszyn, 2016).

The Kaliningrad Oblast located north of the analysed area is quite well developed economically, especially in comparison with other Russian regions (see: Gimbitsky et al., 2014; Kuznetsova, 2015; Wiśniewska et al., 2016). In addition, this whole area has the status of a special economic zone (Gareev, 2013).

From a geopolitical point of view, it can be both a platform for lively cooperation between the EU and Russia (which would benefit the population living in the analysed area), as well as a platform for confrontation (on which it would clearly lose out) (see: Palmowski, 2013; Wendt and Ilieş, 2004; Żęgota, 2018). Of course, the areas located on both sides of the border differ in political, economic and social conditions of development, while they have very similar environmental conditions (Romanova, 2017).

On the entire $210 \mathrm{~km}$ land border of Poland with Russia, there are currently only 4 road border crossing points (Gronowo, Grzechotki, Bezledy, Gołdap) and 2 railway ones (Braniewo, Skandawa, Głomno is currently closed) plus one sea one (Frombork). However, there are proposals to open new connections (Gumenyuk and Studzienicki, 2018). Polish local governments also take part in this by proposing the opening of 5 new border crossings: 2 road (Michałkowo, Pearls), 2 river (Stopki, Węgorapa) and 1 pedestrian (Rapa) one. However, looking at the current political situation, this is unrealistic.

The Polish-Kaliningrad relations are a derivative of Polish-Russian relations and the EURussian ones. They actually started only after 1990 and were characterised by cooperation. However, as a result of the Ukrainian crisis, they cooled down (cf. Żęgota, 2014; Żukowski et al. (eds.), 2018). Therefore, it can be concluded that the state border in question is characterised by low stability and, at the same time, high susceptibility to political influence (Golunov, 2017). The influence of changing international agreements between Poland and Russia on the number of people crossing the border proves the strong impact of politics on the functioning of the Polish-Russian border (fig. 2). In connection with Poland's accession to the European Union, a new agreement was signed between Poland and Russia in September 2003, which introduced a visa requirement for passenger traffic between the two countries. In addition, the Russian authorities introduced the obligation to insure means of transport twice. As a result, there has been a significant decrease in crossing the border (Cichocki, 2004). Subsequently, the introduction of a new visa regime in June 2007 (until then the visa for Polish citizens and the Kaliningrad region was free of charge) resulted in a three-fold decrease in the number of visas issued by the 
Polish consulate in Kaliningrad compared to the previous month, which resulted in a substantial decrease in the number of instances of crossing the border in 2009-2010. On the other hand, the introduction of the so-called local border traffic in July 2012, based on the EU Regulation 1931/2006, was an impulse for an increase in the number of people crossing the border. For example, in 2013, the number of local traffic cards issued by the Polish consulate in Kaliningrad amounted to over 180,000 (whereas, for example, there were less than 80,000 multiple-entry visas) (Studzińska and Nowicka, 2016). This is connected with the maximum in the numbers of instances of crossing the border, which in 2014-2015 amounted to c. $6.3 \mathrm{~m}$ persons a year. This had a positive impact on the Polish local governments affected by this traffic, which recorded a clear economic recovery (Anisiewicz and Palmowski, 2014). Unfortunately, in July 2016 the Polish Ministry of Foreign Affairs suspended the local border traffic with the Kaliningrad Oblast. This resulted in an almost three-fold decrease in the number of instances of crossing the border in 2016 and 2017. Currently, there is a rising trend.

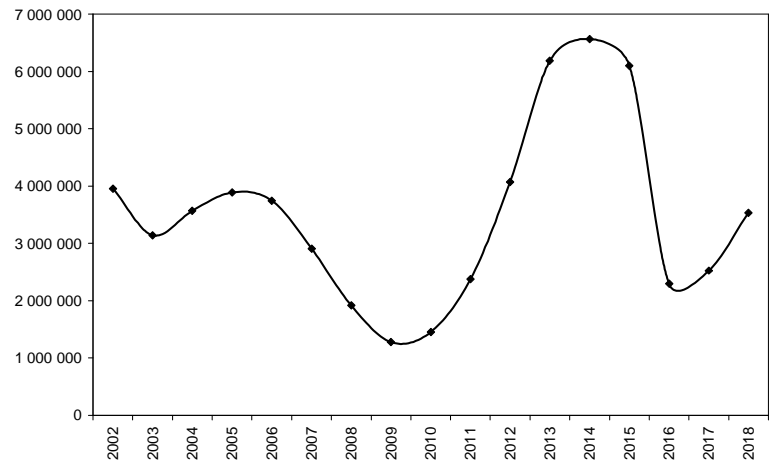

Fig. 2. Number of people crossing the Polish-Russian border in 2002-2018 (Source: Own elaboration based on Statystyki $S G$, 2019).

At present, the situation on the NATO and EURussia lines is exacerbated by the conflict in Ukraine (Kiryukhin, 2016; Roy, 2014), and indirectly by farreaching differences between Russia and EU and NATO countries about the situation in Eastern Europe and beyond (Haukkala, 2015; van Herpen, 2015). This is not conducive to revitalising the exchange on the PolishRussian border.

\section{CONCLUSIONS}

The analysed area is characterised by one of the worst social and economic situations in Poland and there is no indication that the situation could change in the coming years (despite visible progress). Its only important strengths are its natural values, while the biggest weaknesses are the state of the economy and its innovativeness. This will result in depopulation of this region, just as of the whole voivodeship. Potentially, the
Polish-Russian border is a great opportunity for its development. Unfortunately, its functioning depends too much on political factors of a national and global character. As a result, developing a strategy for the Polish border area that would have a high probability of implementation is very difficult.

Fortunately, local governments on both sides do not show excessive interest in politics and focus on the continuation of existing cooperation (Sebentsov and Zotova, 2018). The majority of Polish local governments perceive the potential positive impact of their neighbouring with the Kaliningrad region (which is especially apparent in the development strategies they prepare). But at the same time, local authorities point out the deficiencies in the development of transport infrastructure (including a small number of road border crossings with Russia) and an unstable political situation between Poland and Russia (especially very frequent changes in regulations regarding the crossing of the border by the population) (Polish: Lokalna strategia rozwoju na lata 2009 - 2014 obszaru objętego działaniami LGD Fundacji Lokalna Grupa Działania Partnerstwo dla Warmii, 2009; Polish: Plan Rozwoju Lokalnego Powiatu Bartoszyckiego na lata 2015-2020, 2015; Polish: Plan rozwoju lokalnego. Potencjał powiatu kętrzyńskiego z uwzględnieniem planowanych inwestycji na lata 2007 - 2013, no date; Polish: Strategia rozwoju powiatu gołdapskiego, 2009; Polish: Zintegrowany program rozwoju powiatu węgorzewskiego na lata 2007-2015, 2007).

In the light of the current political situation and tensions between NATO and the EU on the one hand and Russia on the other - the Polish-Russian border should rather not be treated as an opportunity, but on the contrary - if the political situation worsens it may become more of a threat to the local community.

\section{REFERENCES}

Anisiewicz R., Palmowski T. (2014), Small border traffic and cross-border tourism between Poland and the Kaliningrad Oblast of the Russian Federation. Quaestiones Geographica, 33(2), 79-85. DOI: https://doi.org/10.2478/quageo-2014-0017

Bednarek-Szczepańska M. (2017), Rural tourism "an apple of the eye" of rural policy in Poland. Europa XXI, 32, 37-50. DOI: http://doi.org/10.7163/Eu21. 2017.32.3

Bogdański M. (2014), Airports as a factor of regional development on the example of the Szymany Airport. Bulletin of Geography. Socio-economic Series, 25, 1523. DOI: https://doi.org/10.2478/bog-2014-0027

Borowicz A., Kostyra M., Dzierżanowski M., Szultka S., Wandałowski M. (2016), Atrakcyjność inwestycyjna województw i podregionów Polski 2016 [Investment attractiveness of voivodeships and subregions of Poland 2016]. Instytut Badań nad 
Gospodarką Rynkową, Gdańsk. ISBN: 978-83-7615124-3.

Chapman S., Meliciani V. (2018), Explaining regional disparities in Central and Eastern Europe. Economics of Transition, 26(3), 469-494. DOI: https://doi.org/10.1111/ecot.12154

Cichocki B. (2004), Wschodnia granica zewnętrzna rozszerzonej Unii Europejskiej [The Eastern External Border of the Enlarged European Union]. Prace OSW / CES Studies, 14, 5-25.

Czarniawska B. (2014), Social Science Research: From Field to Desk. SAGE Publications, Los Angeles. ISBN: 978-144-62-9394-2.

Dziemianowicz W. (2017), Staying on the old development path, but 'smartly' - a case study of Warmia and Masuria. Miscellanea Geographica Regional Studies in Development, 27(2), 73-78. DOI: https://doi.org/10.1515/mgrsd-2017-0023

Dziemianowicz W., Szlachta J. (2005), Competitiveness of Warmia and Mazury - Problem Diagnosis. Marshal's Office of the WarmińskoMazurskie Voivodeship, Olsztyn. Available online at: http://strategia2025.warmia.mazury.pl/site/showFile/ 75.html?id_menu=65. Acessed on 7.3.2019.

Egidy T., Kovács Z., Kondor A. C. (2017), Metropolitan region building and territorial development in Budapest: the role of national policies. International Planning Studies, 22(1), 14-29, DOI: https://doi.org/10.1080/13563475.2016.1219652

Ezcurra R., Pascual P., Rapún M. (2007), The Dynamics of Regional Disparities in Central and Eastern Europe during Transition. European Planning Studies, 15(10), 1397-1421, DOI: https://doi.org/ 10.1080/09654310701550850

Freyburg T., Lavenex S., Schimmelfennig F., Skripka T., Wetzel A. (2009), EU promotion of democratic governance in the neighbourhood. Journal of European Public Policy, 16(6), 916-934. DOI: https://doi.org/10.1080/13501760903088405

Fritz V. (2007), State-Building: A Comparative Study of Ukraine, Lithuania, Belarus, and Russia. Central European University Press, Budapest. ISBN: 9789637326998.

Gareev T. (2013), The special economic zone in the Kaliningrad region: development tool or institutional trap?. Baltic Journal of Economics, 13(2), 113-129, DOI: https://doi.org/10.1080/1406099X.2013.10840535

German T. (2016), Russia and South Ossetia: conferring statehood or creeping annexation? Southeast European and Black Sea Studies, 16(1), 155-167. DOI: http://dx.doi.org/10.108o/14683857.2016.1148411

Gimbitsky K. K., Kuznetsova A. L., Fedorov G. M. (2014), The development of Kaliningrad regional economy: A new stage of restructuring. Balic Region, 1(19), 41-53. DOI: https://doi.org/10.5922/2079-85552014-1-4
Godlewska-Majkowska H. (n.d.), Atrakcyjność inwestycyjna województwa warmińsko-mazurskiego [Investment attractiveness of Warmian-Masurian voivodeship]. Available online at: https://docplayer.pl/ 1895958-Atrakcyjnosc-inwestycyjna-wojewodztwawarminsko-mazurskiego.html. Accessed on 7.3.2019.

Golunov S. (2016), Organizing against Border Barriers: The Case of EU-Russian Order. Alternatives: Global, Local, Political, 41(3), 154-171. DOI: https://doi.org/10.1177/0304375417691295

Golunov S. (2017), Shuttle Trade across Russia's Borders with the Baltic States and Poland: Between Tolerance and Suppression. East European Politics and Societies and Cultures, 31(4), 885-908. DOI: https://doi.org/10.1177/o888325417725784

Grigorescu I., Dumitraşcu M., Sima M., Micu D. (2016), Crossing the borders. Studies on cross-border cooperation within Danube Region. Case Study: The Euroregion Danube-Kris-Mureş-Tisza. Central European Service for Cross- Order Initiatives, Budapest. ISBN 978-963-12-4756-5.

Gumenyuk I. S., Studzienicki T. (2018), Current and Prospective Transport Connections between Poland's Border Voivodeships and Russia's Kaliningrad Region. Baltic Region, 10(2), 114-132. DOI: https://doi.org/10.5922/2079-8555-2018-2-8

Gwiazdzinska-Goraj M., Jezierska-Tholle A. (2013), Functional Changes of the Rural Areas in Poland. Case Study: Warmińsko-Mazurskie Voivodeship. Journal of Settlements and Spatial Planning, 4(1), 53-58.

Haukkala H. (2015), From Cooperative to Contested Europe? The Conflict in Ukraine as a Culmination of a Long-Term Crisis in EU-Russia Relations. Journal of Contemporary European Studies, 23(1), 25-40. DOI: https://doi.org/14782804.2014.1001822

Hergezelová M. (2017), Regional Development of Eastern Slovakia. Izzivi prihodnosti - Challenges of the Future, 2(3), 178-194.

Ilieş A., Grama V. (2010), The external western Balkan border of the European Union and its borderland. Annales: Anali za istrske in mediteranske studiuje - Series historia et sociologia, 20(2), 457-468.

Ilieş A., Wendt J., Ilieş D. C., Grama V. (2011), Romanian/Ukrainian borderland (northern sector) typology determined by the administrative territorial units (Nuts 3). Central European Regional Policy and Human Geography, 1(2), 7-13.

Ilieş M., Ilieş D. C., Ilieş A., Josan I., Ilieş G. (2010), The gateway of Maramureş land: geostrategical implications in space and time. Annales: Anali za istrske in mediteranske studiuje - Series historia et sociologia, 20(2), 469-480.

Kiryukhin D. (2016), Russia and Ukraine: the clash of conservative projects. European Politics and Society, 17(4), 438-452. DOI: https://doi.org/10.1080/ 23745118.2016.1154130 
Kistowski M. (2013), Atlas sozologiczny gmin Polski 2000-2009 [Sozologic atlas of Polish communes 2000-2009].Wydawnictwo Uniwersytetu Gdańskiego, Gdańsk. ISBN: 978-83-7865-041-6.

Komornicki T., Wiśniewski R., Baransowski J., Błażejczyk K., Degórski M., Goliszek S., Rosik P., Solon J., Stępniak M., Zawiska I. (2015), Wpływ korytarzy drogowych na środowisko przyrodnicze i rozwój społeczno-ekonomiczny [Impact of the selected road corridors on natural environment of the adjacent areas]. IGiPZ PAN, Warszawa. ISBN 97883-61590-61-3

Kriaučiūnas E., Krupickaitè D., PociūtèSereikienè G., Ubarevičienė R. (2014), Lietuvos kaimo gyvenviečių funkcijų kaitos regioninès ypatybès [Regional peculiarities of rural settlement function change in Lithuania]. Geografijos metraštis, 47, 70-87.

Kuznetsova A. (2015), Towards a Stable and Dynamic Economy in the Kaliningrad Region. Balic Region, 3(25), 83-95. DOI: https://doi.org/10.5922/2079-85552015-3-7

Local Data Bank (2019), Statistics Poland, Warsaw. Available online at: https://bdl.stat.gov.pl/BDL/start. Accessed on 7.3.2019.

Lokalna strategia rozwoju na lata 2009 - 2014 obszaru objętego działaniami LGD Fundacji Lokalna Grupa Działania Partnerstwo dla Warmii [Local development strategy for the years 2009 - 2014 of the area covered by the LAG activities of the Foundation Local Action Group Partnership for Warmia] (2009). Fundacja Lokalna Grupa Działania Partnerstwo dla Warmii, Pieniężno. Available online at: http://lgddlawarmii.pl/data/documents/LSR-Partner stwo-dla-Warmii-07.02.2014.pdf.Accessed on 9.3.2019. Mielnik A. (2006), Institutional aspects of Ukraine and Poland`s transborder cooperation: Results and problems. In: Kitowski J. (ed.) Regional transborder cooperation in countries of Central and Eastern Europe - a balance of achievements. Institute of Geography and Spatial Organization PAS, University of Rzeszów, Warsaw - Rzeszów, 117-137.

Miszczuk A. (2013), Uwarunkowania peryferyjności regionu przygranicznego [Conditions of border region peripherality]. Noebretinym, Lublin. ISBN 978-837222-494-4.

Mladenov Ch., Ilieva M. (2012), The depopulation of the Bulgarian villages. Bulletin of Geography. Socioeconomic Series, 17, 99-107. DOI: http://doi.org/ 10.2478/v10089-012-0010-8.

Nemec J. (2014), Comparative analysis of public administrations reforms in former socialist countries of Central and Eastern Europe. International Journal of Civil Service Reform \& Practice, 4, 93-113.

Nikiforova B. (2010), Transforming borders functions in the Lithuanian-Polish-Belarusian Borderland. LIMES, 3(2), 124-132. DOI: http://doi.org/10.3846/ limes.2010.13
Pahl N., Richter A. (2007), SWOT Analysis - Idea, Methodology and a Practical Approach. GRIN Verlag, München. ISBN 978-364-03-0303-8.

Palmowski T. (2013), Kaliningrad - szansa czy zagrożenie dla Europy Bałtyckiej? Monografia społeczno-gospodarcza [Kaliningrad - an opportunity or a threat to Baltic Europe? Socio-economic monograph]. Wydawnictwo "Bernardinum", Gdańsk Pelplin. ISBN 978-83-7823-133-2.

Plan Rozwoju Lokalnego Powiatu Bartoszyckiego na lata 2015-2020 [Local Development Plan of Bartoszycki poviat for 20152020] (2015), Zarząd Powiatu Bartoszyckiego, Bartoszyce. Available online at: https://bipspbar toszyce.warmia.mazury.pl/akty/1044/uchwalenieplanu-rozwoju-lokalnego-powiatu-bartoszyckiego-nalata-2015-2020.html. Accessed on 9.3.2019.

Plan rozwoju lokalnego. Potencjał powiatu kętrzyńskiego z uwzględnieniem planowanych inwestycji na lata 2007 - 2013 [Local development plan. Potential of Kętrzyn poviat with consideration of planned investments for the years 2007 - 2013] (no data). Starostwo Powiatowe w Kętrzynie, Kętrzyn. Available online at: http://starostwo.ketrzyn.pl /_old_bip/get_filee975.pdf?id=144485. Accessed on 9.3.2019.

Program Operacyjny Polska Wschodnia 20142020 (POPW) [Operational Programme Eastern Poland 2014-2020 (POPW)] (2018), Warszawa: Ministerstwo Inwestycji i Rozwoju. Available online at: https://www.polskawschodnia.gov.pl/strony/oprogramie/dokumenty/program-polska-wschodnia2014-2020/. Accessed on 16.10.2018.

REGULATION (EC) No 1931/2006 OF THE EUROPEAN PARLIAMENT AND OF THE COUNCIL of 20 December 2006 laying down rules on local border traffic at the external land borders of the Member States and amending the provisions of the Schengen Convention (2007). Official Journal of the European Union, L93/3.

Roaf J., Atoyan R., Joshi B., Krogulski K., IMF staff team (2014), 25 years of transition: postcommunist Europe and the IMF. International Monetary Fund, Washington, ISBN: 978-1-49834-201-8.

Romanova E. A. (2017), Socioeconomic Conditionality of the Baltic Macroregion Landscape Development and Zoning. Journal of Settlements and Spatial Planning, 8(2), 131-137. DOI: https://doi.org/10.24193/JSSP.2017.2.06

Rosik P., Pomianowski W., Koliszek S., Stępniak M., Kowalczyk K., Guzik R., Gołoś A., Komornicki T. (2017), Multimodalna dostępność transportem publicznym gmin w Polsce, [Multimodal public transport accessibility of Polish gminas/municipalities (MULTIMODACC)], IGiPZ PAN, Warszawa. ISBN 978-83-61590-62-0. 
Roy A. (2014), Russian 'deniable' intervention in Ukraine: how and why Russia broke the rules. International Affairs, 90(6), 1255-1297. DOI: https://doi.org/10.1111/1468-2346.1217

RSI - Regionalna Strategia Innowacyjności Województwa Warmińsko-Mazurskiego do roku 2020 [Regional Innovation Strategy of Warmian-Masurian Voivodeship until 2020] (2010). Urząd Marszałkowski Województwa WarmińskoMazurskiego, Olsztyn. Available online at: http://ris.warmia.mazury.pl/rsi-2010-2020. Accessed on 7.3.2019.

Salukvadze J., Golubchikov O. (2016), City as a geopolitics: Tbilisi, Georgia - A globalizing metropolis in a turbulent region. Cities, 52, 39-54. DOI: https://doi.org/10.1016/j.cities.2015.11.013

Sebentsov A. B., Zotova M. V. (2018), The Kaliningrad Region: Challenges of the Exclave Position and the Ways to Offset Them. Baltic Region, 10(1), 89106. DOI: https://doi.org/10.5922/ 2079-8555-2018-16

Sekuła A. (2012), Local development - the definition aspect in the 21 st century. In: Company at the turn of the 21 st century. Politechnika Rzeszowska, Rzeszów, 59-64.

Size of Polish airports - passenger traffic and aircraft movements in domestic and international market in scheduled and charter services in 2015 - 2017 (2018), Civil Aviation Authority, Warsaw. Available online at: http://www.ulc.gov.pl/en/publications/statictics-andanalysis-of-air-transport-market/3974-statistics-byairports. Accessed on 7.3.2019.

Smutek J. M., Lonyszyn P. (2016), Cross-border issues in Polish supraregional strategies on example of strategies of western and eastern Poland. Journal of Geography, Politics and Society, 6(2), 32-44. DOI: https://doi.org/10.4467/24512249JG.16.011.5456

Statystyki SG [SG statistics] (2019), Warszawa: Komenda Główna Straży Granicznej. Available online at: https://www.strazgraniczna.pl/pl/granica/statystyk i-sg/2206,Statystyki-SG.html. Accessed on 7.3.2019.

Stokłosa K. (2012), Neighborhood Relations on the Polish Borders: The Example of the Polish-German, Polish-Ukrainian and Polish-Russian Border Regions. Journal of Borderlands Studies, 27(3), 245-255. DOI: http://doi.org/10.1080/o8865655.2012.750948

Strategia rozwoju powiatu gołdapskiego [Development strategy for the district of Gołdapski] (2009). Starostwo Powiatowe w Gołdapi, Gołdap. Available online at: http://arch.powiatgoldap.pl /charakterystyka-powiatu/item/5-strategia-rozwoju.

Accessed on 9.3.2019.

Strategia Rozwoju społeczno-gospodarczego województwa warmińsko-mazurskiego do roku 2025 [Socio-economic development strategy of Warmian-Masurian Voivodeship until 2025] (2013).
Urząd Marszałkowski w Olsztynie, Olsztyn. Available online at: http://strategia2025.warmia.mazury.pl/. Accessed on 7.3.2019.

Studzińska D., Nowicka K. (2016), Ruch bezwizowy na zewnętrznych granicach Unii Europejskiej na przykładzie granicy polsko-rosyjskiej [The visa free traffic at the European Union external borderson the example of the Polish-Russian order]. Rozwój Regionalny i Polityka Regionalna, 34, 45-58.

Szymańska W. (2016), Borders as barriers (based on the example of European post-Communist countries). Journal of Geography, Politics and Society, 6(2), 7-12. DOI:

http://dx.doi.org/10.4467/24512249JG.16.008.545

van Herpen M. H. (2015), Putin's wars: the rise of Russian's new imperialism. Rowman \& Littlefield, Lanham. ISBN 978-4422-3138-2.

Vodichev E., Glazyrina I., Krasnoyarova B. (2016), Transboundary cooperation on the east of Russia: regional development and institutional bottlenecks. Journal of Geography, Politics and Society, 6(2), 13-20. DOI: https://doi.org/10.4467/24512249 JG. 16.009.5454

Wendt J., Ilieş A. (2004), Kaliningrad: Region de menace ou de cooperation?. In: Richard Y., Sanguin A. L. (eds.) L' Europe de l'Est quinze ans apres la chute du mur. L'Harmattan, Paris, 35-40.

Więckowski M. (2001), Granica polityczna jako bariera dla rozwoju i funkcjonowania transportu w Karpatach Zachodnich [A political border as a barrier to the development and functioning of transport in Western Carpathians]. Prace Komisji Geografii Komunikacji PTG, 7, 201-221.

Wiśniewska I., Domańska M., Strzelecki J., Żochowski P., Wilk A., Menkiszak M. (2016), Kaliningrad Oblast 2016. The Society, Economy and Army. Centre for Eastern Studies, Warsaw. Available online at: https://www.osw.waw.pl/sites/default/files/ raport_in_the_kaliningrad_net.pdf. Accessed on 16.10.2018.

Xheneti M., Smallbone D., Welter F. (2013), EU enlargement effects on cross-border informal entrepreneurial activities. European Urban and Regional Studies, 20(3), 314-328. DOI: https://doi. org/10.1177/o969776411434849

Zielone Płuca Polski w 2015 r. [Green Lungs of Poland in 2015] (2017). Urząd Statystyczny w Białymstoku, Białystok. Available online at: https://stat.gov.pl/obszary-tematyczne/srodowiskoenergia/srodowisko/zielone-pluca-polski-w-2015-r,3,4.html. Accessed on 7.3.2019.

Zintegrowany program rozwoju powiatu węgorzewskiego na lata 2007-2015 [Integrated Development Programme for the poviat of Węgorzewo for the years 2007-2015] (2007). Starostwo Powiatowe w Węgorzewie, Węgorzewo. Available online at: http://bip.powiatwegorzewski.pl/akty/o/649/w_spraw 
ie_uchwalenia_Zintegrowanego_Programu_Rozwoju_ Powiatu_Wegorzewskiego_na_lata_2007_E2_80_93 _2015/.Accessed on 7.3.2019.

Zupančič J., Wendt J. A., Ilieş A. (2018), An outline of border changes in the area between the Baltic and the Mediterranean: Their geopolitical implications. Geographia Polonica, 91(1), 33-46. DOI: https://doi.org/10.7163/GPol.o104

Żęgota K. (2014), Polityczne i prawnomiędzynarodowe uwarunkowania polsko-rosyjskiej umowy o małym ruchu granicznym [Political and international conditions of Polish-Russian agreement on local border traffic]. Przegląd Geopolityczny, 8, 213-227.
Żegota K. (2018), The Kaliningrad Oblast: An Area of Cooperation and Conflict of Interests between the Russian Federation and the West. Ulpaper of the Swedish Institute of International Affairs, 3/2018, 2934.

Żukowski A., Chełminiak M., Kotowicz W., Żęgota K. (eds.) (2018), Mały ruch graniczny w warunkach kryzysu w relacjach polsko-rosyjskich [Small border traffic in conditions of crisis in PolishRussian relations]. INP UWM, Olsztyn, ISBN 978-83895-5970-8. 